[Peters, M. A., Peters, M. C., \& Freeman-Moir, J. (1992). The 1991 Budget and Tertiary Education: Promises, Promises.... New Zealand Annual Review of Education, 1, 133-146]

\section{The 1991 Budget and Tertiary Education: Promises, Promises...}

\author{
Michael A. Peters, Michael C. Peters and John \\ FREEMAN-MOIR
}

$T^{\mathrm{h}}$ 1991 Budget, described by Ruth Richardson in the news media as "the Mother of all Budgets", in effect represents the most brutal assault on the welfare state we have witnessed in New Zealand. Its provisions have been even more far-reaching than the Treasury ideologues and other members of the New Right might have dreamed possible in the heady days of the 1980s. In terms of social policy we have seen a disestablishment of the foundations of the welfare state: the move from universalistic premises to targeting social assistance; the privatisation of the health system; the commercialisation of the Housing Corporation; a reneging on promises in superannuation and education; the emergence of greater state surveillance in the form of "information sharing" between government agencies. All this as part of devising "a strategy for enterprise and growth" based on three objectives - the reform of the labour market (completed under the Employment Contracts Act, 1991), "redesigning" the welfare state, and managing fiscal problems. Ironically, like Saddam's conquest of Kuwait, Ruth Richardson's strategy has turned out to be full of empty promises and U-turns. The "Mother of all Budgets" gave birth to a puny child which has needed all the life support systems that modern neo-liberal politics demand: expert PR to obfuscate the real issues; sheer repetition of claims; the stifling of internal dissent; and the stubborn ideological refusal to admit that many policies have been the product of haste, compromise and collusion. The tertiary education "reforms" put in place as a result of the 1991 July Budget are a perfect illustration - a case in point. The Minister of Finance's speech as the preamble to the Budget reveals in general technocratic terms the place of education:

\section{Michael A. Peters, Michael C. Peters \& John Freeman-Moir}

A key element of the Government's strategy is to boost skills and technological knowledge throughout society. In an increasingly competitive world, the quality of our education, science and technology will play a big role in our future prosperity (Budget 1991, p. 7).

In practical policy terms for education what does this mean? The document, Education Policy (1991, p. 3) lays out the four key elements of the new policy: Parents as First Teachers; The Achievement Initiative; The National Certificate; and Study Right. Only the last of these is in the area of tertiary education. This paper, accordingly, will concentrate mainly on examining the changes brought about by the introduction of Study Right. It will also outline briefly and make some comment on the new capital charging regime to be introduced for all tertiary institutions in 1993. The paper concludes with a discussion of the notion of competitive neutrality.

\section{Study Right}

\section{Background and description}

The Study Right concept emerged as a central component of the Government's Skills Policy (February, 1990) which attempts to develop a holistic approach in tertiary education and training based on the notions of flexibility (wider options), portability (easy transfer between courses and institutions), qualifications (nationally recognised levels of attainment), and performance (skills for a high-growth economy). It was originally conceived in terms of a universalistic rights-based rationale, guaranteeing every school leaver access to tertiary education and training, in a form suited to his or her individual need. In essence, this was the basis for the Minister of Education's promise to abolish the standard tertiary fee of $\$ 1,300$ established by the previous government.

The Review of Study Right (1991), by one of the three Tertiary Review Groups established by the Cabinet Expenditure Control Committee in December 1990, indicated in their evaluation of the original proposal that the Government would be unable to guarantee a place to all Study Right candidates as envisaged. The review team found "major deficiencies in the proposal which outweigh its advantages" and, in particular, commented that: 
Study Right is a poorly targeted programme that will hamper the development of the tertiary sector as a forum for adult and recurrent education, by displacing mature age students out of the tertiary sector (The Review of Study Right, April 1991, p. 1).

Reflecting the goals of social reforms as outlined in the Economic and Social Initiative (1990) - i.e., the need to make fiscal savings by reducing expenditure on education, health and housing, and at the same time to ensure that those in real need are not deprived of access to essential services - the review team's evaluation highlights the trade-offs between the Government's fiscal goals (e.g., reducing expenditure) and its social goals for increasing overall participation in education and training, and upskilling in the labour market. The review team argued that these competing objectives could only be achieved if the role and responsibility of the state in the payment of income support were radically redefined. Such a redefinition, they maintained, necessarily would affect the level, form and structure of assistance, as well as the traditional balance between public and private funding and provision. It would also affect eligibility criteria for assistance. The review team argued that a rights-based approach, where education is regarded as a positive right of all citizens on moral grounds, suffers a major deficiency in that "it gives Ministers little guidance about tradeoffs in allocating scarce resources for the attainment or maintenance of different rights" (p. 16).

The resulting recommendations bear all the marks of compromise: the review team argued that students should contribute towards the costs of tertiary education which could be achieved by a reduction in the level of state subsidy and by allowing providers to set fees in a competitive environment. They added that any move to increase the direct costs of tuition should be coupled with the introduction of arrangements for students to finance these costs. It should also be noted that the review team recommended the abolition of the standard tertiary tuition fee and that the conditions of Study Right entitlement be relaxed to include all those who are currently within the workforce. In effect, both the review team's recommendations and the resulting policy of Study Right that emerged in the Budget back away from a universalistic rights-based rationale to one that favours targeted social assistance.
In summary, the key changes introduced under Study Right include:

- a 95\% subsidy of tuition costs for all tertiary students under 22 years for the first three years of undergraduate study;

- those not eligible in terms of the age criterion or who have used up their entitlement will receive a $75 \%$ tuition subsidy;

- research-based post-graduate students will compete for scholarships covering $95 \%$ of their tuition costs and the others will receive a $75 \%$ subsidy;

- tertiary institutions are free to set their own fees;

- student allowances for 16-24 year olds are to be means tested;

- under a loans scheme students are able to borrow to cover compulsory tuition fees, course-related costs (up to $\$ 1,000$ ), and living expenses (maximum of $\$ 4,500$ less any entitled allowance) at $8.2 \%$ interest with income-related repayments starting at $\$ 12,670$ on entering the workforce;

- the abolition of the means-tested fees rebate for 18-19 year olds.

The major claim accompanying these measures is that by reducing the cost of student allowances and establishing a loans scheme, the Government is able to substantially increase the number of subsidised student places and reduce tuition costs for most students. The Government claims it will fund some 14,000 more places in tertiary education and training through Study Right and that the fee for a typical first year Arts student will fall from $\$ 1300$ to around $\$ 350$ (The Budget, 1991, p. 21). Both claims are exaggerated. Boston (1992) believes that once pipeline growth is taken into account fewer places will be provided by Government funding. As for student fees, a part from Otago where Study Right students are charged \$500 in Arts, Commerce, Education, Law and Theology, all other fields are at least twice that estimated in the Budget.

\section{Assessing the impact of the changes}

A number of commentators have discussed the likely impact of the changes. Perhaps predictably the University Students Association have been amongst the severest critics of Study Right. The Association have pointed to the way the new scheme, as instituted by some universities, 
discriminates on the basis of course and age. Emma Reid, President of NZUSA, is reported as stating that up to $65 \%$ of tertiary students would lose all their allowances and that many students are already in debt, with a national average debt loading of \$1674 (The Press, 14.10.91).

The New Zealand Vice-Chancellor's Committee, in their newsletter (August 1991, No. 16, p. 2) indicated that they accepted the principle that students derive a private benefit from tertiary education and therefore should be expected to pay a contribution towards its provision. The NZVCC, however, "believes it is inequitable to levy a 25 per cent fee and to vary the amount payable according to the cost of course delivery." The Committee noted that the fee differentials resulting from Study Right could have a serious impact on expensive professional and post-graduate programmes. It also voiced concern over issues concerning entitlement and duration of Study Right and the fact that students would suffer a decrease in their living allowances following decisions announced in the Budget.

An editorialin The Press (8.10.91) entitled "Study Wrong" viewed the scheme as a hasty compromise between three influences: the belief that students should contribute to their education, the need to limit spending while trying also to increase tertiary places and the promise by the Minister of Education to abolish the $\$ 1,300$ tertiary fee. It described Study Right as illogical and commented that it "enables the Government to "abolish" the tertiary fee but still claw back savings through imposing a parental income test on allowances for those under 25 years." The editorial also indicated the way in which the scheme acts as a barrier to certain specialist courses, to mature students, and to graduate research.

Others have emphasised the most harmful changes in more detail. Both Boston (1991) and Tobias (1991) have strongly criticised the way in which the distinction introduced between school leavers and matureaged students is disastrous in economic and social terms. Tobias (1991, p. 6), for instance, writes:

[Study Right] fails to meet the requirements of a dynamic economy in a period of increasingly rapid technological and social change. It is simply nolonger possible for people to assume that the knowledge and skills acquired through their initial occupational education and training will be sufficient to see them through their working lives.
Periods of recurrent education and training are essential both for those who remain in relatively stable employment and even more critically for those who face redundancy and unemployment. The Budget does nothing to promote recurrent education. To the contrary its tertiary fees policies provide a disincentive for people 22 or more from returning to study."

Both Boston and Tobias raise additional concerns:

the fact that Study Right covers students for three years when many undergraduate courses are four years or longer; that the strong emphasis on fee differentiation on the basis of course costs and age is likely to be highly inequitable; that the postgraduate subsidy penalises those wishing to take such courses and, accordingly, has negative implications for university research; that the new policy makes single students aged 20-24 years heavily dependent on their parents; that it causes all sorts of distortions - it adds to administrative costs, it impacts most severely on low and middle income families, it increases the effective marginal tax rate for many families, it provides all sorts of incentives for abuse, and it compromises New Zealand's longstanding open-entry policy (Boston, 1991, p. 2).

In terms of the impact of the funding changes on public expenditure (tertiary education), Boston (1991, p. 4) estimates that it could actually fall this year and over the medium term as a result of the Budget. The changes will vary in their impacts on different tertiary institutions affecting negatively those with a high proportion of mature students and/or expensive courses. The distributional consequences of the changes are singled out by Boston (1991, pp. 7-8) as being very severe:

Overall, it has been estimated that $27,000-30,000$ of those tertiary students aged 16-24 who currently receive some form of income support will no longer be eligible for assistance. This is roughly $40 \%$ $50 \%$ of the group in question. It has been estimated, for example, that more then $50 \%$ of Canterbury University students will lose all their living allowance next year and, of course, many more will lose part of their allowance.

With the abolition of the means-tested rebate for 18-19 year olds it is not just middle income families who will suffer financially. Families on less 
than $\$ 27,000$ will lose a subsidy worth over $\$ 1,100$. The impact on tertiary participation rates is almost impossible to calculate but Boston claims that we will witness a shift to more part-time study, with more people better off on the dole than pursuing full-time courses.

Further, Study Right has been criticised for failing to meet the needs of a democratic society by curtailing support for continuing education and community development programmes, cutting back on the already low level of state funding in these areas (Tobias, 1991, p. 6). These are the crucial programmes which tend to cater for women, working class men and Maori people who are less likely to pursue tertiary education as school leavers and more likely to return to formal education as adults on a part-time basis.

Tobias (1991, p. 7) indicates that the Budget and the new education policy have been driven by the cost-cutting demands of the Cabinet Expenditure Control Committee, a narrow political agenda and a set of pragmatic concerns. At a deeper level, he suggests, that the Budget "may be seen as one episode or outcome in an ongoing struggle between the forces of the 'New Right' and those democratic, welfarist and socialist forces which oppose them."

Assessing the full impact of the changes is difficult at the time of writing when it is not clear yet how many students, both school leavers and mature-aged people, have decided not to pursue their education or what kind of debt loading those students who have decided to return have assumed. This kind of data will not be available until later in the year and a full evaluation of the impact will not be known for some years as the fee structures of tertiary institutions first increase over the next few years and then possibly stabilise.

Three universities have introduced a flat fee based on arguments for cross-subsidisation. For 1992 Waikato University has introduced a flat fee of $\$ 894$, Canterbury University, a flat fee of $\$ 1,000$ and Auckland University a flat fee of $\$ 1,050$. Elsewhere differentiated fee structures have been introduced based on course and age criteria: for example, Otago University has a five-level fee scale based on courses where nonStudy Right students have to pay almost twice as much in each cost band, well in excess of the $\$ 1,300$ standard tertiary fee for the most expensive courses; Lincoln University has a three-tier cost structure with non-Study Right students paying up to $\$ 264$ more; Christchurch
Polytechnic has opted for a two-fee plan where Study Right students pay $\$ 770$ and non-Study Right pay $\$ 1,510$; Christchurch College of Education has also introduced a differentiated cost structure where older trainees pay substantially more, sometimes more than twice as much, depending on the course.

The emergence of differentiated cost fee structures will undoubtedly penalise students from poorer backgrounds and mature students and act as a disincentive for them taking more expensive courses. It will also add substantially to administrative costs without necessarily improving the efficiency or responsiveness of institutions.

\section{The underlying arguments}

Despite the present Minister's pre-election criticisms of the Labour Government's proposal to introduce user charges for tuition and meanstesting for student allowances, the National Government has seen fit to extend means-testing to students aged 25 years and replace the standard tuition fee with an arguably less generous Study Right. With justification, the Government has been publicly criticised both for backtracking on election promises and for relying on the ideological principles espoused by the Treasury and the Business Roundtable. What has been lacking in all of this is some public discussion and consideration of the arguments of user pays and loans schemes in tertiary education.

According to its supporters, not only is user pays a more equitable way of distributing the costs of tertiary education, ensuring fair access to all, it is also seen to promote efficiency, responsiveness, student performance and quality. The equity argument is the one that might be seen to exercise appeal to the taxpaying public at large. A system can hardly be fair if it charges one group of people - i.e., tax-payers - for the benefits accrued by another group - i.e., university students. If students are getting most of the benefits from their education then they ought to pay for it, so the argument goes. This assertion is often accompanied by arguments about "middle class capture" and is used to justify the means-testing of allowances.

The argument here crucially rests on the assumption that tertiary education is a private satisfaction rather than a public good. It ignores the externalities (e.g., an informed populace or advances in science and 
research) of tertiary education or assumes them to be of little consequence. The central difficulty is that many of the external benefits are unquantifiable and it becomes impossible and arbitrary to calculate what proportion of the costs students ought to contribute. The equity argument, then, collapses on practical grounds at the point where attempts are made to impose costs according to a ratio of private to public benefits, and one is left with arguments about efficiency. Certainly, this much is conceded in The Tertiary Review (1991).

The efficiency argument is presented on a number of fronts. First, The Tertiary Review presents the rather bizarre idea that a non user-pays system means "that everyone has the right to an unlimited amount of education at the State's expense" and that user-pays will somehow deter students from becoming over-educated. Apart from the definitional and conceptual difficulties over the notion of being "overeducated", it should be recognised that the government has never paid a full allowance to students. Even before the introduction of user-pays students were experiencing a loss of potential earnings with many accumulating debts during their time of study. It is, therefore, problematic to assume that there can be efficiency savings here.

The next assertion centres on the idea that fee paying students will become "more discerning and critical customers" who are likely to put pressure on institutions to decrease costs and improve quality. This presupposes an environment of competition which forces institutions to respond to student demand. Such competition, however, requires the duplication of facilities and equipment, the cost of which would ultimately be passed on to the consumer or taxpayer. Furthermore, the choice of an institution will not be determined purely by quality and cost but also by a range of other factors including geographic proximity and the status of degrees offered by different institutions.

Questions ought to be raised about the promise of quality under a user-pays system, assuming that the term has an unproblematic application to education. Even if a high degree of competition could be established it is doubtful that it would enhance or protect the existing "quality" of tertiary education. This is so because in international terms university education in New Zealand has always represented "value for money". In recent years the effects of funding cuts and increasing student to staff ratios have reached a point where teaching resources have been stretched to the limit. It is unlikely, therefore, that competition will generate further savings without compromising the quality of teaching or the range of courses offered.

On a different tack, politicians have argued that the education system is not doing enough to respond to the needs of the labour market. User-pays will remedy this, it is argued, by inducing students to take account of labour market "signals" when they choose the courses they will take. The underlying assumption here is that user pays will lead to a more efficient economy because the demands of the labour market will always call forth the appropriate number and type of graduates. Such an argument ignores the fact that market-led policies often result in crises of over-production. It also assumes perfect rational choice on the part of individuals based on perfect information which is available to everyone. Furthermore, at a time of "big science" where many of the largest industrial nations are focussing on research and development as a basis for continuous and sustained economic growth, manpower planning strategies have become more popular. User-pays and associated loans schemes do not promote the necessary long term generational perspective and may, in fact, lead to a massive reduction in post-graduate research training.

Another assertion made in favour of the alleged efficiency of user pays is that it will provide an incentive for students to apply themselves in their studies. No empirical evidence supports this claim. It could be argued that imposing a greater financial burden could impair student performance, with many pulling out of courses or giving up during the year. Further, high levels of stress and anxiety with consequent health problems cannot be ruled out as unimportant.

If each of these assertions is doubtful and open to question, then the case for user-pays might be made purely on pragmatic grounds which emphasise the need for student contributions to fund extra places in tertiary education. Objections to this move may be made on two counts. First, as the present Minister noted in his criticisms of Labour Government policy when he was in the Opposition, the accumulated revenue from such an exercise may not be as significant as expected because the administrative costs are likely to be greater than first thought. Further, the Government will have to write off debts both for defaulters and for those whose income does not reach the critical level. 
Evidence from West Germany and the USA shows that only about a quarter of loans are paid back in full. Second, evidence from Sweden shows an $11 \%$ reduction in enrolments following the introduction of their loans scheme (Springett, 1986, p. 9). User pays, therefore, may even discourage participation in tertiary education. More disturbing, perhaps, is the fact that the reduction involved students predominantly from working class backgrounds. This does not sit well with the stated concern of the Treasury (1987) and The Tertiary Review (1991, p. 32) for the middle class capture of university education and the underrepresentation of disadvantaged groups. The user-pays system may not deliver its promises of equity, efficiency and quality in tertiary education. What is worse, it may create the very opposite of its intended effects.

\section{Capital Charging}

As part of the provisions of the Budget, Education Policy (1991) announced that the Government had agreed in principle to a new scheme for the capital charging of state tertiary education institutions, to be in troduced from January 1993. The term simply means a charge on the physical capital of institutions including land and buildings. In 1990-91 three departments (Government Superannuation Fund, Health and Treasury) piloted a capital charge incentive regime, introduced to encourage them to manage their fixed and working capital more efficiently i.e., to minimise the amount of capital they are using to produce their outputs and to maximise the cash proportion of their working capital. Under the capital charge regime, to apply to all departments from 1 July 1991, departments pay the Crown a capital charge of $13 \%$ on the average level of taxpayers' funds recorded in their statement of financial position. They also earn interest on cash balances. The cost structure faced by departments supposedly now mirrors that of any other producer in the economy. The capital charge regime is seen as a management rather than a fiscal measure which is allegedly fiscally neutral.

The new capital charging scheme for tertiary institutions thus follows Government policy for all departments and its rationale is to strengthen the incentives for efficient management of the state's $\$ 1.8$ billion investment in the assets of tertiary institutions. Issues yet to be resolved in consultation with the institutions include the identification and valuation of assets to which the charge should apply, the appropriate rate of charge on assets, and the treatment of endowments and historical buildings.

The Tertiary Review (1991) identified four alternative models of asset ownership including the state owned enterprise (SOE) and private ownership models along with current institutional arrangements and the capital charging scheme. Current arrangements were not seen as being a framework which provides strong enough incentives for efficiency and responsiveness. Perhaps, surprisingly, both the private and SOE models were deemed as inappropriate for non-profit organisations. Both assume that the Government's social objectives could be met through purchase and the suitability of the EFTS (Equivalent Full Time Student) bulk funding arrangements in achieving this, thereby ignoring other objectives of ownership such as ensuring continuity of provision. In addition, concerns were expressed about academic freedom should Councils be replaced with an appointed Board of Directors and whether there would be buyers willing to offer a good price. The review team recommended a capital charge scheme as it was thought that it would capture many of the possible benefits while minimising the costs and risks. Furthermore, such a scheme does not preclude revisiting other options later. Nevertheless, it is clear that the Council structure will be reviewed in future to improve the representation of the Government's ownership interest on Councils by increasing the use of the provision for Ministerial appointees to Councils.

While both the corporatisation and privatisation options have not been favoured it still remains an open question at this stage as to how the new scheme will affect principles of institutional autonomy and academic freedom, and the extent to which it implies a commercialisation of tertiary education. Certainly, it does imply a further set of policy changes the full effects of which are difficult to judge at this stage given the lack of detail.

\section{Competitive Neutrality and Freedom}

Competition is the cornerstone of market liberal reform in tertiary education. Competitive neutrality is said to obtain where institutions exist in a situation which provides neither competitive advantage nor disadvantage. Publicly funded institutions allegedly discourage 
competition on a neutral basis because they hold an advantage over private institutions and thus "crowd them out" of the market place. This is seen by market liberals to lead to a number of problems. First, it allegedly results in a lack of freedom of choice which undermines the very principle of democracy. Second, without competition institutions allegedly have no incentive to be effective or cost efficient. So seriously are the beneficial effects of competition or "contestability" taken that attempts are being made to introduce it at every level. The introduction of user pays is a "demand side" strategy designed to force "consumers" to adopt a more critical attitude when choosing which institution they will attend. This is buttressed on the "supply side" by a whole raft of strategies including capitation funding (a voucher scheme without vouchers), asset charging, allowing institutions to set their own fees, Government subsidies to private institutions, and competition for research funding though the Foundation for Research, Science and Technology. As the Tertiary Review (1991, p. 9) succinctly notes:

promoting competitive neutrality and contestable provision, through requiring a return on capital and existing public funding to private providers, together with more flexibility in setting fees, will reduce constraint on overall supply and potentially increase student choice, improving the incentive for responsiveness to student demand.

Providing an environment which fosters competition in a free market supposedly brings greater freedom of choice in two ways: either existing institutions become more responsive to the needs of students or new institutions spring up to cater for untapped demand.

This free market ideology, as Codd $(1989$, p. 6) notes, is a "powerful source of legitimation" because it sits well with popular sentiment about state imposition on individual freedom. However, the "freedom" of market liberals is only the freedom to pursue wealth in the labour market. Lauder $(1987$, p. 7) makes the point well when he argues that this notion of freedom:

is better captured by theeconomic term consumer sovereignty because it draws attention to the fact that choice is governed by the dictates of the market which in turn is governed by the drive for profit.

Given the rising costs of tertiary education, increasingly students are forced to choose courses, not freely but those which will provide the most relief from debt. Clearly, the notion of freedom espoused by market liberals is not one of "empowerment" but rather one which fits individuals passively into the labour market, with all its attendant "unfreedoms" structured along the lines of race, class, gender and age.

\section{References}

Boston, J. “The Funding of Tertiary Education", notes prepared for an address to the AUS, Victoria University, Wellington, 7 August, 1991.

Boston J. "The Funding of Tertiary Education - Rights and Wrongs" in Boston, J. and Dalziel, P. (Eds.) National Economic and Social Politics. Auckland, OUP, 1992

Codd, J. "Educational Reform in New Zealand: Devolution or Control?". Paper presented at the Annual Conference of the British Educational Research Association, University of Newcastle-upon-Tyne, 30 August2 September, 1989.

Lauder, H. "The New Right and Educational Policy in New Zealand" in New Zealand Journal of Educational Studies, Vol. 22, No. 1, 1987, pp. 3-33.

The Tertiary Review, (Reports of the Tertiary Review Group). Wellington, Ministry of Education, 1991.

Richardson, R. Minister of Finance Budget 1991. Wellington, Government Printer, 1991.

Smith, L. Minister of Education Education Policy: Investing in People, Our Greatest Asset, ,Wellington, Government Printer, 1991.

Springett, B. P. User Pays and Social Equity. Palmerston North, Massey University, (Mimeo), 1986.

The Treasury Government Management, Vols. $1 \mathcal{E} 2$. Wellington, Government Printer, 1987.

Tobias, R. "Lifelong Learning and the 1991 Budget", paper presented at the Annual Conference of the New Zealand Association for Community and Continuing Education, Masterton, 30 August-2 September, 1991.

\section{The authors}

Michael A Peters is a Lecturer in the Education Department at the University of Canterbury with interests in the fields of philosophy of education and education policy.

Michael C Peters is a PhD candidate in the Education Department at the University of Canterbury. He is completing research on New Zealand universities.

John Freeman-Moir is a Senior Lecturer and joint Head of Department in the Education Department at the University of Canterbury. His interests are in the politics and sociology of education. 